This is the postprint version of the article published in Fisheries Research, 195, p. 180-185 (2017) http://dx.doi.org/10.1016/j.fishres.2017.07.012

\title{
Economy matters: A study of mislabeling in salmon products from two regions, Alaska and Canada (Northwest of America) and Asturias (Northwest of Spain)
}

\author{
Marta Muñoz-Colmenero ${ }^{1 *}$, Francis Juanes ${ }^{2}$, Eduardo Dopico ${ }^{3}$, Jose Luis Martinez ${ }^{4}$, Eva \\ Garcia-Vazquez ${ }^{1}$ \\ 1: Department of Functional Biology; 3: Department of Education Sciences; 4: Unit of DNA \\ Analysis of Scientific and Technical Services, University of Oviedo, C/Julian Claveria s/n, \\ 33006, Oviedo, Asturias, Spain.
}

2: Department of Biology, University of Victoria, Victoria, BC, V8W 3N5, Canada.

\begin{abstract}
Mislabeling of seafood species has negative economic, social and ecological consequences, from consumer losses due to fraudulent exchange, undermining consumer awareness, to hiding illegal and unreported catches. Salmonids are no exception. They are an important part of the culture and economy of many countries in the northern hemisphere, and identifying possible causes of salmon mislabeling is of great interest, even more so where wild species and species from aquaculture are consumed. Here different types of commercial unrecognizable salmonid products (111 in total) from Asturias in Northwest Spain (Atlantic Ocean), and Alaska and Vancouver Island in Northwest America (Pacific Ocean) were analyzed by DNA Barcoding. The Spanish and Northwest American samples were mislabeled $6 \%$ and $23.8 \%$ respectively. Species substitutions were respectively wild-farmed and wildwild, substitute species being cheaper. Economic reasons and social preference of wild over farmed products seem to be the main drivers in the exchanges detected in this study. Enhancing controls over the unrecognizable products to prevent this type of fraud is essential and strongly recommended.
\end{abstract}

\section{Keywords}

Socioeconomic perspectiveSalmonTroutMislabelingCOI

\section{Introduction}

Fish mislabeling results in a series of varied negative consequences that have been well summarized by Jacquet and Pauly (2008). The economic advantages for the defrauders that obtain profits by selling cheaper species for more expensive fish represent losses in duties and import taxes for governments, as well as inadvertent economic losses for the consumers that buy an unwanted product at expensive prices. At the social level, fraud undermines efforts of sustainable fisheries and aquaculture, and consumer's eco-awareness. For example, if the fish are sustainably caught as it happens for instance for South African hake (Marine Stewardship Council: certified sustainable seafood 2004; as https://www.msc.org/) but are sold abroad under a wrong label (Garcia-Vazquez et al., 2011, Muñoz-Colmenero et al., 2015), the enormous effort of stakeholders for achieving sustainability cannot be recognized by the unaware foreign consumer. Other consequences are ecological. Mislabeling may hide cases of illegal fisheries, for example: the complex case of Pacific rockfish (Logan et al., 2008), endangered angel shark mixed with other sharks (Ardura et al., 2011), mislabeling of cod products in China markets (Xiong et al., 2016), the use of Gadus chalcogrammus as substitute of Merluccius merluccius (Ferrito et al., 2016), and others.

One case of special importance from a social point of view are salmonids. Wild salmonids are an essential part of traditional cultures in many societies of the northern Hemisphere, both in North America (Finney et al., 2000; Raby et al., 2012) and Europe (Briton, 2014, Valiente et al., 2011) as well as key economic resources especially along the North Pacific American coast. On the other hand, some species such as the Pacific rainbow trout Oncorhynchus mykiss and the Atlantic salmon Salmo salar are widely cultivated. Wild 
and farmed salmonids are differently appreciated by consumers worldwide, for example, Verbeke et al. (2007) found that consumers slightly preferred wild over farmed fish on the attributes of taste, health and nutritious value. Consumer's perception about which seafood type conveys the highest quality clearly favors fish and shellfish harvested from the wild, with $53 \%$ of consumers preferring wild-caught seafood in the USA (O'Dierno et al., 2006). Wild salmon is preferred at least in part due to the general belief that farmed fish contain more mercury than wild fish (average 68.5\% European consumers; Pieniak et al., 2013).

The use of DNA is required to identify the species when fish are sold in pieces or processed in any way so that their morphological characteristics cannot be recognized (MuñozColmenero et al., 2015). Several studies applying DNA Barcoding have reported mislabeling in salmonids (e.g.: Pardo et al., 2016, Cawthorn et al., 2012, Cline, 2012, Warner et al., 2013, Wong and Hanner, 2008). In these studies (Table 1) the species substituted with is often farmed salmon for wild salmon (e.g., Atlantic salmon sold instead of king salmon Oncorhynchus tshawytcha; Cline, 2012), or trout instead of salmon (e.g. rainbow trout instead of Atlantic salmon; Cawthorn et al., 2012). The substitutions may encompass changes between species from different oceans (Table 1), the Oncorhynchus genus being native to the North Pacific and the Salmo genus native to the North Atlantic Ocean, although in the case of farmed species hatcheries can be located anywhere in temperate climates.

In this study we have analyzed samples of different salmonid products purchased from public marketplaces on the west coast of North America (Alaska in USA and Vancouver Island in Canada) and in Europe (Principate of Asturias, in the North of Spain, Bay of Biscay). We have performed the sampling in these places due to the high importance of salmonids products, being one of the most common fish type consumed and marketed in those regions (Hanner et al., 2011, Rasmussen et al., 2011, Larios, 1930). In addition, in these places the wild salmon species are very appreciated and with enormous cultural value, with several examples of ancestral traditions related with salmonids (Lynn et al., 2013, Valiente et al., 2011, Blanco et al., 2005). Due to such, we consider those regions as adequate for our study. The main aim of this work was to identify by DNA Barcoding methodology the species contained in salmon processed products, in order to assay the reliability of the labeling of such products in the two regions involved in the study. The expectations were that, in the case of existing mislabeling, any substitute species would be the nonnative and farmed species in each region, exchanging species from Oncorhynchus genus by Salmo genus and vice versa, which are the most common misidentifications detected in the other works (e.g.: Pardo et al., 2016 and Table 1).

\section{Material and methods}

\subsection{Products analyzed}

We obtained samples from local grocery stores in Alaska (USA), Vancouver Island (Canada), and Asturias (North of Spain), choosing one representative city in each target region, in which the salmon products market is high. All products purchased were processed products, being sold as: jerky, candy salmon, slices, loins, etc. (Table 2), and therefore being impossible to recognize the species by their morphological features.

In Alaska and Canada the analyzed products were salmon jerky and candy salmon, which are widely marketed and consumed in those regions. Furthermore, due to the high degree of processing of those samples, they are considered as a good niche for the species exchange, being usually labeled only with the commercial common name, as was the case of the samples analyzed here (Table 2). A total of 31 products sold as salmon jerky were purchased in Anchorage, Alaska, USA from three local marketplaces in the summer of 2013 (Table 2). In Vancouver Island (Victoria, Canada), a total of 13 products were purchased, four salmon jerky and nine candy salmon pieces also from local grocery stores (4). 
The samples from Asturias (Northwest Spain) (67) were purchased in six different grocery stores in Oviedo city (Asturias, Bay of Biscay), Spain. These products were more variable because in this region the consumption of processed salmonids products is similar between the different types. The majority of the samples (48) were heavily processed products (canned, smoked, salted, pâte) and the rest of the samples (19) were less processed products (fresh or frozen pieces).

In both regions the sampling was mainly focused on highly processed products since the mislabeling in those products may be higher (Muñoz-Colmenero et al., 2016, Filonzi et al., 2010, Rasmussen and Morrissey, 2008), and they are subject to more permissive laws than the products sold whole and fresh.

For all products and regions the expected species were determined from the information found on the labels and shown in Table 2.

\subsection{DNA barcoding}

DNA extraction was performed following the protocol developed by Estoup et al. (1996) using Chelex resin. DNA was extracted directly from a $\sim 5 \mathrm{~mm}^{3}$ piece of fresh or frozen samples. All the other kind of products were previously cleaned with a 2:1:0.8 solution of distilled water, chloroform, and methanol in order to remove potential inhibitors of posterior PCR as oils, salts, etc., not present in frozen and fresh products. A fragment of the Cytochrome oxidase subunit I gene (COI) was amplified using the primers designed by Ward et al. (2005). The PCR conditions were: initial denaturation at $95^{\circ} \mathrm{C}$ during $5 \mathrm{~min}$ followed by 35 cycles of $20 \mathrm{~s}$ at $95{ }^{\circ} \mathrm{C}, 20 \mathrm{~s}$ at $57^{\circ} \mathrm{C}$ for annealing and $30 \mathrm{~s}$ at $72{ }^{\circ} \mathrm{C}$ for elongation. Finally, an extension step of $72{ }^{\circ} \mathrm{C}$ for $10 \mathrm{~min}$. PCR was performed in $20 \mu \mathrm{L}$ of total volume, and the composition was: $2.5 \mu \mathrm{M} \mathrm{Mg}^{2+}$, reaction buffer of Promega Taq polymerase $1 \times, 0.75 \mathrm{U}$ Promega Taq enzyme $(5 \mathrm{U} / \mu \mathrm{L}), 2.5 \mathrm{mM}$ of each $\mathrm{dNTP}, 1 \mu \mathrm{M}$ primers, $2 \mu \mathrm{L}$ of DNA, and bi-distilled water up to the total volume. PCR products were checked in $2 \%$ agarose gel stained with $3 \mu \mathrm{L}$ ethidium bromide $(0.5 \mu \mathrm{g} / \mu \mathrm{L})$, purified with Illustra Exostar 1-Step (GE Healthcare Life Sciences), sequenced at the DNA Analysis Facility of the University of Oviedo with the BigDye Terminator Cycle Sequencing Kit v3.1 and analyzed on a 3130xl Genetic Analyzer (Applied Biosystems) Automated Sequencer.

The sequences were manually checked with the BioEdit v 7.0.9.0 Sequence Alignment Editor Software program (Hall, 1999). They were aligned using the Clustal W tool included in BioEdit (Thompson et al., 1994). To assign the species, the nucleotide BLAST tool (nBLAST) located in the GenBank public database from NCBI (http://www.ncbi.nlm.nih.gov/) was employed, with $99 \%$ of identity as cut-off. This cut-off is conservative enough to resolve the identification at the species level but keeps $1 \%$ for possible intraspecific variability. Those sequences in which mislabeling was found were also checked with the Barcode of Life Database (BOLD; http://www.boldsystems.org/) to ensure our results.

Additional analysis to confirm species identification through neighbor-joining trees was conducted. Reference sequences of known species were downloaded from GenBank and aligned with the haplotypes found in our study. The best-fit evolution model for our dataset was determined by the program jModelTest 0.1.1 (Posada, 2008), using the Akaike information criterion. The tree was performed following the same criteria as Ardura et al. (2010), including the same nucleotide evolution model (Tamura-Nei) and replicates (2000), and employing MEGA version 6 (Tamura et al., 2013).

\subsection{Statistical analyses}

Mislabeling was compared between samples using Chi-square contingency tests $\left(\chi^{2}\right)$ with the software included in Microsoft Excel (version 2010). Yates's correction (Yates, 1984) for small sample sizes was performed. 


\section{Results and discussion}

All the products analyzed in this study except one sample from Alaska and one from Victoria (both salmon jerky) yielded DNA of enough quality for successful PCR amplification of the COI gene. This represents $98.2 \%$ success, and emphasizes the utility of DNA Barcoding for identification of fish species in processed seafood (Armani et al., 2015, Galal-Khallaf et al., 2014, Cawthorn et al., 2012, Wong and Hanner, 2008).

In total, after DNA analyses, we obtained 23 sequences of Oncorhynchus tshawytscha (from 33 expected), corresponding with six haplotypes (sequence variants), 23 sequences of Oncorhynchus keta (from 13 expected), corresponding with three haplotypes, 50 sequences of Salmo salar (from 50 expected), corresponding with six haplotypes, 3 sequences of Oncorhynchus gorbuscha (from 3 expected), corresponding with one haplotype, and 10 sequences of Oncorhynchus mykiss (from 4 expected), corresponding with two haplotypes. Lastly, no sequences were obtained for Salmo trutta (from 4 expected). All the haplotypes (18 in total) were submitted to the GenBank database, with the accession numbers KU756202KU756219.

Our results revealed substitution in the salmon trade (Table 3), confirming previous studies (Table 1; Pardo et al., 2016). Barcoding unambiguously identified 14 mislabeled products that provided COI sequences of high identity with GenBank and BOLD reference sequences of substitute species (Table 4). The phylogenetic analysis confirmed the results obtained from BLAST methodology, with the haplotypes of the mislabeled samples clustered with the substitute species (Fig. 1).

However, the proportion of mislabeled products was not identical in the two areas studied. It was $6 \%$ in Spanish samples and 23.8\% in the samples obtained from northwest America (significant difference with $\chi^{2}=7.154$, d.f. $=1, p<0.01$ ). Indeed the type of products was different between locations, as Spanish samples included frozen and fresh products. When we removed these products (less processed) from the Spanish samples the percent mislabeling was still significantly lower than in America (7.3\%; 3 mislabeled over 41 highly processed products, $\chi^{2}=4.904$, df $=1, p<0.05$ ).

The type of substitution was different in the two regions. In northwest America it was in all cases Oncorhynchus keta labeled and sold as O. tshawytscha, both products of wild catches, while the four Spanish cases were wild native brown trout Salmo trutta replaced by farmed rainbow trout Oncorhynchus mykiss. In Europe the mislabeling of the analyzed samples, as expected, corresponds to a change of wild species for farmed fish. Wild brown trout is a noncommercial species in the region (Spanish Law 6/2002 of June 18, available in Spanish at https://www.boe.es/buscar/act.php?id=BOE-A-2002-15998, accessed February 2016) and its catch is strictly restricted to sport fishing (angling), although it is unlikely that common consumers know this regulation. An enormous difference in price occurs between brown trout and substitute species in other countries where Salmo trutta can be commercialized; for example in Scotland loch trout (Salmo trutta) and rainbow trout (O. mykiss) are sold at 14.29 and $3.50 £ / \mathrm{kg}$ respectively in UK supermarkets (http://www.mysupermarket.co.uk/grocerycategories/Fresh_Salmon_And_Trout_in_Tesco.html, accessed February 2016). European consumers perceive farmed fish as more contaminated than wild fish (Pieniak et al., 2013), and it seems logical that any mislabeling try to please consumer preferences for wild fish.

In our North American samples the substitution was between species with wild catches, not wild-farmed. This may be explained by different prices of these two species. For example, in Alaska in 2013 the prices (average US\$/pound fish) were: King (Oncorhynchus tshawytscha) 6.72, versus Chum (O. keta) 1.50

(http://www.alaskaseafood.org/industry/market/January2014SMB/salmon-price-report.html, accessed February 2016). In a Washington State marketplace as much as $11 \%$ substitution of Pacific salmon for Atlantic salmon was found (Cline, 2012). The small sample size analyzed from the United States could explain the absence of this type of substitution in our study. However, the explanation could be also economic. The price of farmed Atlantic 
salmon Salmo salar was higher than that of Chum salmon in Alaska (1.81 US\$/pound fresh fish; http://www.agmrc.org/commodities-products/aquaculture/, accessed February 2016). It would be economically advantageous to use Chum salmon, not Atlantic salmon, as substitute for king (spring) salmon. Although an exchange driven by economic reasons seems to make sense, we have to consider the option that the season is also an influence. Other studies such as Pardo et al., (2016) have mentioned that the substitution of Oncorhynchus species by Salmo species is higher in winter, when the wild species are not available. In those months the sellers have only the cultivated species to do the exchanges.

Seafood supply is increasingly obtained farther from the consumption site (Watson et al., 2015). However, the substitute species found in this study are likely produced in situ, since Oncorhynchus mykiss is cultured in Europe, and the substitute species found in Northwest America have also local presence. To our surprise the results indicate that substitutes are not always farmed fish. Economic reasons seem to prevail in salmonid frauds, coincident with wild-farmed changes in some cases but not in all, perhaps depending on the availability of other wild species for use as substitutes. Such substitutions should be controlled by governments or associations for the protection of consumer rights, especially in regions where salmon is a resource with high cultural value. Reiterated mislabeling cases can undermine the consumeŕs interest for the salmonids, leading to the loss of part of cultural traditions related with their consumption. In addition, more effort is necessary from governments to ensure that the consumers know the regulations, at least in fishes commonly consumed, as is the case of salmon or trout. This would favor the participation of the consumers in the application of rules through their selections during their purchase times. For instance, if the consumers knew that Wild brown trout must not be available to buy in the Spanish markets, when they see this species they will be alerted.

On the other hand, the substitute species could be suffering an inadvertent fishing pressure that the responsible control agencies should be taking into account. For instance in this study, in the Pacific North American coast, some populations of the wild substitute O. keta have been lost in North America, as well as some major life-history types (Gustafson et al., 2007). Despite the fact that most Alaskan salmon fisheries have been certified as sustainable by the Marine Stewardship Council, there have already been cases of other species certified as sustainable in which mislabeling problems have been found, as for example Chilean sea bass (Marko et al., 2011). Therefore, the mislabeling cases between King and Chum salmon should be revised in order to check that the wild populations of those regions continue being sustainable. In addition, the species that is substituted could reflect a wrong conclusion that it is more available than it really is, resulting in errors in the estimates of catches, that may destabilize the calculation of stock sizes, and confusion of the awarded consumers (MuñozColmenero et al., 2015). More studies checking if the individuals used in the exchanges detected between these two salmon species are wild, from farms or both would be also appropriate to have more control over the situation of wild populations and the possible effects of the mislabeling.

\section{Conclusions}

By authenticating different types of commercial processed salmon and trout products in the Northwest of America (Alaska, Vancouver Island) and Northwest of Spain (Principate of Asturias), by cytochrome oxidase I gene as DNA Barcode, different mislabeling in the regions considered has been detected. Substitutions of wild-wild were found in America whereas wild-farmed were found in Spain. Different consumer preferences and above all different prices of the involved species explain these cases suggesting that the retailers or final sellers may profit from these exchanges. From this work the need of more regulation is clear to both control the fraud in those species which are commonly used in the food market, and to prevent potential adverse ecological consequences. Furthermore, a transparent market with efficient mislabeling control plans are needed in order to avoid the undermining of the consumer's confidence in food safety and the loss of their interest about what they must buy to protect natural resources. 


\section{Funding sources}

This study was supported by the Principality of Asturias under the Grant GRUPIN-2014-093. MMC holds a Spanish National Grant (FPU) (reference AP-2010-5211).

\section{Conflict of interest}

The authors declare no competing financial interest.

\section{Acknowledgment}

We are grateful to D. Serna for his help with laboratory tasks.

\section{References}

A. Ardura, I.G. Pola, A.R. Linde, E. Garcia-Vazquez DNA-based methods for species authentication of Amazonian commercial fish Food Res. Int., 43 (2010), pp. 2295-2302

A. Ardura, A. Jardón, E. Hernández, J.L. Martinez, E. Garcia-Vazquez DNA analysis reveals potential risk for fish species conservation derived from mislabeling of dietetic complements J. Food Agric. Environ., 9 (2011), pp. 53-56

A. Armani, L. Guardone, R. La Castellana, D. Gianfaldoni, A. Guidi, L. Castigliego DNA barcoding reveals comercial and health issues in ethnic seafood sol don the Italian market Food Control, 55 (2015), pp. 206-214

G. Blanco, M.D. Ramos, E. Vázquez, J.A. Sanchez Assessing temporal and spatial variation in wild populations of Atlantic salmon with particular reference to Asturias (Northern Spain) rivers J. Fish Biol., 67 (Sup. A) (2005), pp. 169-184

E. Briton Ghost boats and human freight: the social wellbeing impacts of the salmon ban on Lough Foyle's fishing communities J. Urquhart, T.G. Acott, D. Symes, M. Zhao (Eds.), Social Issues in Sustainable Fisheries Management, MARE Publication Series, University of Amsterdam, The Netherlands (2014), pp. 143-164

D.-M. Cawthorn, H.A. Steinman, R.C. Witthuhn DNA barcoding reveals a high incidence of fish species misrepresentation and substitution on the South African market Food Res. Int., 46 (2012), pp. 30-40

E. Cline Marketplace substitution of Atlantic salmon for Pacific salmon in Washington State detected by DNA barcoding Food Res. Int., 45 (2012), pp. 388-393

A. Estoup, C.R. Largiader, E. Perrot, D. Chourrout Rapid one-tube DNA extraction for reliable PCR detection of fish polymorphic markers and trans-genes Mol. Mar. Biol. Biotechnol., 5 (1996), pp. 295-298

V. Ferrito, V. Bertolino, A.M. Pappalardo White fish authentication by COIBar-RFLP: toward a common strategy for the rapid identification of species in convenience seafood Food Control, 70 (2016), pp. 130-137

L. Filonzi, S. Chiesa, M. Vaghi, F. Nonnis Marzano Molecular barcoding reveals mislabelling of commercial fish products in Italy Food Res. Int., 43 (2010), pp. 1383-1388

B.P. Finney, I. Gregory-Eaves, J. Sweetman, M.S.V. Douglas, J.P. Smol Impacts of climatic change and fishing on Pacific salmon abundance over the past 300 years Science, 290 (2000), pp. 795-799

A. Galal-Khallaf, A. Ardura, K. Mohammed-Geba, Y.J. Borrell, E. Garcia-Vazquez DNA barcoding reveals a high level of mislabeling in Egyptian fish fillets Food Control, 46 (2014), pp. 441-445

E. Garcia-Vazquez, J. Perez, J.L. Martínez, A.F. Pardinas, B. Lopez, N. Karaiskou, M.F. Casa, G. Machado-Schiaffino, A. Triantafyllidis High level of mislabelling in Spanish and Greek hake markets suggests the fraudulent introduction of African species J. Agric. Food Chem., 59 (2011), pp. 475-480 
R.G. Gustafson, R.S. Waples, J.M. Myer s, L.A. Weitkamp, G.J. Bryant, O.W. Johnson, J.J. Hard Pacific salmon extinctions: quantifying lost and remaining diversity Conserv. Biol., 21 (2007), pp. 1009-1020

T.A. Hall BioEdit: a user-friendly biological sequence alignment editor and analysis program for Windows 95/98/NT Nucleic Acids Symp. Ser., 41 (1999), pp. 95-98

R. Hanner, S. Becker, N.V. Ivanova, D. Steinke FISH-BOL and seafood identification: geographically dispersed case studies reveal systemic market substitution across Canada Mitochondrial DNA, 22 (Sup.1) (2011), pp. 106-122

J.L. Jacquet, D. Pauly Trade secrets: renaming and mislabeling of seafood Mar. Policy, 32 (2008), pp. 309-318

P. Larios Ríos salmoneros de Asturias [Salmon rivers of Asturias.] Consejo Superior de Caza y Pesca, Madrid (1930)

C.A. Logan, S.E. Alter, A.J. Haupt, K. Tomalty, S.R. Palumbi An impediment to consumer choice: overfished species are sold as Pacific red snapper Biol. Conserv., 141 (2008), pp. 1591-1599

K. Lynn, J. Daigle, J. Hoffman, F. Lake, N. Michelle, D. Ranco, C. Viles, G. Voggesser, P. Williams The impacts of climate change on tribal traditional foods Clim. Change, 120 (2013), pp. $545-556$

P.B. Marko, H.A. Nance, K.D. Guynn Genetic detection of mislabeled fish from a certified sustainable fishery Curr. Biol., 21 (2011), pp. R621-R622

M. Muñoz-Colmenero, M. Klett-Mingo, E. Díaz, O. Blanco, J.L. Martínez, E. GarcíaVázquez Evolution of hake mislabeling niches in commercial markets Food Control, 54 (2015), pp. 267-274

M. Muñoz-Colmenero, O. Blanco, V. Arias, J.L. Martines, E. García-Vázquez DNA authentication of fish products reveals mislabeling associated with seafood processing Fisheries, 41 (2016), pp. 128-138

L.J. O’Dierno, S. Islam, R. Govindasamy, J.J. Myers, V. Puduri The United States Market for Organic Seafood

(2006) Available at the New Jersey Department of Agriculture website http://www.jerseyseafood.nj.gov (Accessed February 2016).

M.A. Pardo, E. Jiménez, B. Pérez-Villarreal Misdescription incidents in seafood sector Food Control, 62 (2016), pp. 277-283

Z. Pieniak, F. Vanhonacker, W. Verbeke Consumer knowledge and use of information about fish and aquaculture Food Policy, 40 (2013), pp. 25-30

D. Posada jModelTest: phylogenetic model averaging Mol. Biol. Evol., 25 (2008), pp. 1253 1256

G.D. Raby, M.R. Donaldson, S.G. Hinch, D.A. Patterson, A.G. Lotto, D. Robichaud, K.K. English, W.G. Willmore, A.P. Farrell, M.W. Davis, S.J. Cooke Validation of reflex indicators for measuring vitality and predicting the delayed mortality of wild coho salmon bycatch released from fishing gears J. Appl. Ecol., 49 (2012), pp. 90-98

R.S. Rasmussen, M.T. Morrissey DNA-based methods for the identification of commercial fish and seafood species Compr. Rev. Food Sci. Food Saf., 7 (2008), pp. 280-295

R.S. Rasmussen, A.M. Naaum, S.M. Handy, R.H. Hanner, J.R. Deeds, F. Yancy, M.T. Morrissey Interlaboratory evaluation of a real-time multiplex polymerase chain reaction method for identification of salmon and trout species in commercial products J. Agric. Food Chem., 59 (2011), pp. 876-884 
K. Tamura, G. Stecher, D. Peterson, A. Filipski, S. Kuman MEGA6: molecular evolutionary genetics analysis version 6.0 Mol. Biol. Evol., 30 (2013), pp. 2725-2729

J.D. Thompson, D.G. Higgins, T.J. Gibson CLUSTAL W: improving the sensitivity of progressive multiple sequence alignment through sequence weighting, position specific gap penalties and weight matrix choice Nucleic Acids Res., 22 (1994), pp. 4673-4680

A.G. Valiente, F. Juanes, E. Garcia-Vazquez Increasing regional temperatures associated with delays in atlantic salmon sea-run timing at the southern edge of the European distribution Trans. Am. Fish. Soc., 140 (2011), pp. 367-373

W. Verbeke, I. Sioen, K. Brunsø, S. De Henauw, J. Van Camp Consumer perception versus scientific evidence of farmed and wild fish: exploratory insights from Belgium Aquacult. Int., 15 (2007), pp. 121-136

R.D. Ward, T.S. Zemlak, B.H. Innes, P.R. Last, P.D.N. Hebert DNA barcoding Australia's fish species Philos. Trans. R. Soc. B, 360 (2005), pp. 1847-1857

K. Warner, W. Timme, B. Lowell, M. Hirshfield. Oceana Study Reveals Seafood Fraud Nationwide. OCEANA Publications (2013) http://oceana.org/reports/oceana-study-revealsseafood-fraud-nationwide (Accessed February 2016).

R.A. Watson, G.B. Nowara, K. Hartmann, B.S. Green, S.R. Tracey, C.G. Carter Marine foods sourced from farther as their use of global ocean primary production increases Nat. Commun., 6 (2015), p. 7365

E.H.-K. Wong, R.H. Hanner DNA barcoding detects market substitution in North American seafood Food Res. Int., 41 (2008), pp. 828-837

Xiong et al., 2016

X. Xiong, L. Guardone, A. Giusti, L. Castigliego, D. Gianfaldoni, A. Guidi, A. Armani

DAN barcoding reveals chaotic labeling and misrepresentation of cod (Xue) products sold on the Chinese market Food Control, 60 (2016), pp. 519-532

F. Yates Test of significance for $2 \times 2$ contingency tables J. R. Stat. Soc. Ser. A Stat. Soc., 147 (1984), pp. 426-463 
Fig. 1. Neighbor-joining tree reconstructed with the MEGA6 program and Tamura-Nei model, from references taken from NCBI database, identified with the letter R at the end, and the haplotypes obtained from the commercial fish products analyzed in this study, identified with the species name expected from the label. All the S. salar and O. gorbuscha haplotypes and one O. keta haplotype (identified with a cross) resulted from products purchased in Spain. The rest resulted from products purchased in USA. Mislabeled samples cluster with references of a different species. Bootstrap values $>96 \%$ are shown.

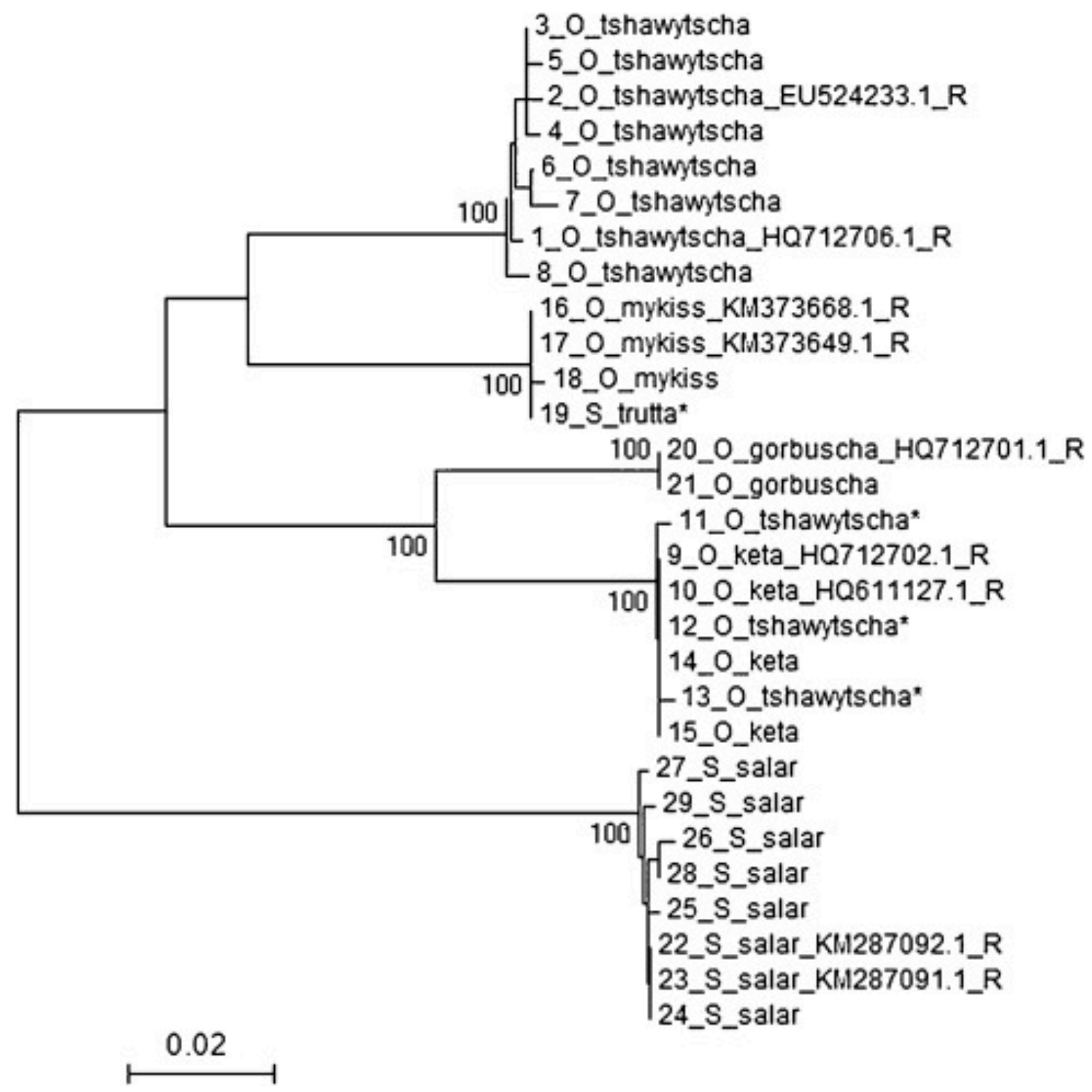


Table 1. Examples of mislabeling reported in salmonids. Percent of mislabeling reported, and percent of Salmo

salar and Oncorhynchus (any species) declared in the labels and found from DNA in each study.

Mislabeling detected

\begin{tabular}{|c|c|c|c|c|c|c|c|}
\hline Region & $\mathbf{N}$ & & $\begin{array}{l}\text { Salmo } \\
\text { salar }\end{array}$ & Oncorhynchus spp. & $\begin{array}{l}\text { Salmo } \\
\text { salar }\end{array}$ & Oncorhynchus spp. & Reference \\
\hline South Africa & 12 & $8.3 \%$ & $75 \%$ & $25 \%$ & $66.7 \%$ & $33.3 \%$ & $\begin{array}{l}\text { Cawthorn } \\
\text { et al. } \\
(2012)\end{array}$ \\
\hline $\begin{array}{l}\text { Northeastern } \\
\text { America }\end{array}$ & 9 & 0 & $55.6 \%$ & $44.4 \%$ & $55.6 \%$ & $44.4 \%$ & $\begin{array}{l}\text { Wong and } \\
\text { Hanner } \\
(2008)\end{array}$ \\
\hline USA & 384 & $7.3 \%$ & $5 \%$ & $95 \%$ & $9.6 \%$ & $90.4 \%$ & $\begin{array}{l}\text { Warner et } \\
\text { al. (2013) }\end{array}$ \\
\hline $\begin{array}{l}\text { Washington } \\
\text { State }\end{array}$ & 99 & $20.2 \%$ & 0 & 100 & $11.3 \%$ & $88.7 \%$ & $\begin{array}{l}\text { Cline } \\
(2012)\end{array}$ \\
\hline
\end{tabular}

\section{Real species}

Salmo Oncorhynchus spp. Reference
salar

(2012)

Wong and

Hanner

Warner et

(2012) 
Table 2. Salmonid products purchased. The total number of samples collected by place is showed in bold.

\begin{tabular}{|c|c|c|c|c|}
\hline Place & $\begin{array}{l}\text { Local } \\
\text { Store }\end{array}$ & $\begin{array}{l}\text { Product } \\
\text { type }\end{array}$ & Processing type & Labeled name \\
\hline \multirow{3}{*}{ Alaska (USA) } & A1 & $\begin{array}{l}\text { Salmon } \\
\text { Jerky }\end{array}$ & Jerky & Wild king salmon \\
\hline & $\mathrm{A} 2$ & $\begin{array}{l}\text { Salmon } \\
\text { Jerky }\end{array}$ & Jerky & Wild king salmon \\
\hline & A3 & $\begin{array}{l}\text { Salmon } \\
\text { Jerky }\end{array}$ & Jerky & $\begin{array}{l}\text { Certified catchWild Alaskan } \\
\text { salmon }\end{array}$ \\
\hline \multirow{5}{*}{$\begin{array}{l}\text { Vancouver Island } \\
\text { (Canada) }\end{array}$} & V1 & $\begin{array}{l}\text { Salmon } \\
\text { Jerky }\end{array}$ & Jerky & Chum salmon \\
\hline & $\mathrm{V} 2$ & $\begin{array}{l}\text { Salmon } \\
\text { candy }\end{array}$ & candy & Spring salmon \\
\hline & V3 & $\begin{array}{l}\text { Salmon } \\
\text { candy }\end{array}$ & candy & Spring salmon \\
\hline & V4 & $\begin{array}{l}\text { Salmon } \\
\text { candy }\end{array}$ & candy & Spring salmon \\
\hline & $\mathrm{S} 1$ & Paté & paté & Salmo salar \\
\hline \multirow{10}{*}{ Asturias (Spain) } & $\mathrm{S} 2, \mathrm{~S} 3, \mathrm{~S} 4$ & Smoked & smoked sheets & Salmo salar \\
\hline & $\mathrm{S} 4$ & Smoked & smoked sheets & Salmo trutta \\
\hline & S5 & Canned & canned pieces & Salmo salar \\
\hline & S6 & Salted & salted loins & Oncorhynchus keta \\
\hline & & Salted & salted loins & Oncorhynchus gorbuscha \\
\hline & & Fresh & slices & Norwegian salmon \\
\hline & $\mathrm{S} 2, \mathrm{~S} 3$ & Fresh & $\begin{array}{l}\text { without head and } \\
\text { scrape }\end{array}$ & Rainbow trout \\
\hline & S3 & Fresh & $\begin{array}{l}\text { without head and } \\
\text { scrape }\end{array}$ & Brown trout \\
\hline & $\mathrm{S} 2$ & Frozen & frozen slices & Pacific O.gorbuscha \\
\hline & & Frozen & frozen fillets & Norwegian salmon \\
\hline
\end{tabular}


Table 3. Commercial products analyzed in North America and Spain. Cases of mislabeling are shaded in grey. The total number of products analyzed and the mislabeling found from each continent are marked in bold.

\begin{tabular}{|c|c|c|c|c|c|c|c|c|}
\hline Region & Product & On the label & Type & Expected species & Real species from DNA & Real type & $\mathrm{N}$ & Mislabeling \\
\hline \multirow[t]{3}{*}{ Alaska } & Salmon jerky & King salmon & Wild & $\begin{array}{l}\text { Oncorhynchus } \\
\text { tshawytscha }\end{array}$ & Oncorhynchus keta & Wild & 1 & \\
\hline & & King salmon & Wild & $\begin{array}{l}\text { Oncorhynchus } \\
\text { tshawytscha }\end{array}$ & $\begin{array}{l}\text { Oncorhynchus } \\
\text { tshawytscha }\end{array}$ & Wild & 23 & \\
\hline & & Alaska salmon & Wild & Oncorhynchus keta & Oncorhynchus keta & Wild & 6 & \\
\hline \multirow[t]{3}{*}{$\begin{array}{l}\text { Vancouver } \\
\text { Island }\end{array}$} & Salmon candy & Spring salmon & Wild & $\begin{array}{l}\text { Oncorhynchus } \\
\text { tshawytscha }\end{array}$ & Oncorhynchus keta & Wild & 9 & \\
\hline & Salmon jerky & Chum salmon & Wild & Oncorhynchus keta & Oncorhynchus keta & Wild & 3 & \\
\hline & & & & & Total North America & & 42 & $23.8 \%$ \\
\hline \multirow[t]{12}{*}{ Spain } & Paté & Salmo salar & Farmed & Salmo salar & Salmo salar & Farmed & 3 & \\
\hline & Smoked & Salmo salar & Farmed & Salmo salar & Salmo salar & Farmed & 33 & \\
\hline & Smoked & Salmo trutta & Wild & Salmo trutta & Oncorhynchus mykiss & Farmed & 3 & \\
\hline & Canned & Salmo salar & Farmed & Salmo salar & Salmo salar & Farmed & 3 & \\
\hline & Salted & $\begin{array}{c}\text { Oncorhynchus } \\
\text { keta }\end{array}$ & Wild & Oncorhynchus keta & Oncorhynchus keta & Wild & 4 & \\
\hline & Salted & $\begin{array}{l}\text { Oncorhynchus } \\
\text { gorbuscha }\end{array}$ & Wild & Oncorhynchus gorbuscha & Oncorhynchus gorbuscha & Wild & 2 & \\
\hline & Fresh & Norwegian salmon & Farmed & Salmo salar & Salmo salar & Farmed & 9 & \\
\hline & Fresh & Rainbow trout & Farmed & Oncorhynchus mykiss & Oncorhynchus mykiss & Farmed & 6 & \\
\hline & Fresh & Brown trout & Wild & Salmo trutta & Oncorhynchus mykiss & Farmed & 1 & \\
\hline & Frozen & $\begin{array}{l}\text { Pacific } O \text {. } \\
\text { gorbuscha }\end{array}$ & Wild & Oncorhynchus gorbuscha & Oncorhynchus gorbuscha & Wild & 1 & \\
\hline & Frozen & Norwegian salmon & Farmed & Salmo salar & Salmo salar & Farmed & 2 & \\
\hline & & & & & Total Spain & & 67 & $5.97 \%$ \\
\hline
\end{tabular}


Table 4. DNA-based evidence of mislabeling found in this

study. Haplotype, GenBank reference of the sequence found in our

study. Percentage of coverage (\%Cov) and identity (\%Ide) with the

closest match reference found in GenBank and BOLD by nBLAST methodology.

\begin{tabular}{llllllll} 
Region & Expected species & $\begin{array}{l}\text { Real species } \\
\text { from DNA }\end{array}$ & Haplotype & $\begin{array}{l}\% \\
\text { Cov }\end{array}$ & $\begin{array}{l}\text { \% } \\
\text { Ide }\end{array}$ & $\begin{array}{l}\text { GenBank } \\
\text { ref. }\end{array}$ & $\begin{array}{l}\text { BOLD } \\
\text { ref. }\end{array}$ \\
\hline Alaska & $\begin{array}{l}\text { Oncorhynchus } \\
\text { tshawytscha }\end{array}$ & $\begin{array}{l}\text { Oncorhynchus } \\
\text { keta }\end{array}$ & KU756204 & 100 & 99 & JX960914.1 & AAA3872 \\
Vancouver & $\begin{array}{l}\text { Oncorhynchus } \\
\text { tshawytscha }\end{array}$ & $\begin{array}{l}\text { Oncorhynchus } \\
\text { keta }\end{array}$ & KU756203 & 99 & 99 & JX960914.1 & \\
Island & Salmo trutta & $\begin{array}{l}\text { Oncorhynchus } \\
\text { mykiss }\end{array}$ & KU7564 & 100 & 99 & JX960914.1 & AAA3872 \\
Spain & KU756205 & 100 & 99 & JX960915.1 & \\
& & & 100 & JX960921.1 & AAA1627
\end{tabular}

